\title{
Bombesin-like Peptide Mediates Lung Injury in a Baboon Model of Bronchopulmonary Dysplasia
}

\author{
Mary E. Sunday, ${ }^{\star}$ Bradley A. Yoder, ${ }^{\ddagger}$ Frank Cuttitta, ${ }^{\S}$ Kathleen J. Haley, ${ }^{\mathbb{I}}$ and Rodica L. Emanuel ${ }^{\|}$ \\ *Department of Pathology, Children's Hospital, Brigham \& Women's Hospital, and Harvard Medical School, Boston, Massachusetts \\ 02115; ${ }^{\ddagger}$ Department of Pediatrics, Wilford Hall Medical Center, Lackland AFB, Texas 78236 and Southwest Foundation for Biomedical \\ Research, San Antonio, Texas 78228; ${ }^{\S}$ National Cancer Institute, National Institutes of Health, Cell and Cancer Biology, Rockville, \\ Maryland 20850; "Department of Medicine, Children's Hospital and Harvard Medical School, Boston, Massachusetts 02115; and \\ "Department of Medicine, Division of Pulmonary-Critical Care, Brigham \& Women's Hospital and Harvard Medical School, Boston, \\ Massachusetts 02115
}

\begin{abstract}
The etiology of bronchopulmonary dysplasia (BPD), a chronic lung disease of infants surviving respiratory distress syndrome, remains fundamentally enigmatic. BPD is decreasing in severity but continues to be a major problem in pediatric medicine, being especially prevalent among very premature infants. Increased numbers of pulmonary neuroendocrine cells containing bombesin-like peptide (BLP) have been reported to occur in human infants with BPD. We tested the hypothesis that BLP mediates BPD using the hyperoxic baboon model. Urine BLP levels increased soon after birth only in $100 \% \mathrm{O}_{2}$-treated 140 -d animals which developed BPD, correlating closely with severity of subsequent chronic lung disease. Similar elevations in urine BLP were observed in the 125-d baboon "interrupted gestation" model of BPD. Postnatal administration of anti-BLP antibody attenuated clinical and pathological evidence of chronic lung disease in the hyperoxic baboon model. Urine BLP could be a biological predictor of infants at risk for BPD, and blocking BLP postnatally could be useful for BPD prevention. ( $J$. Clin. Invest. 1998. 102:584-594.) Key words: radioimmunoassay $\bullet$ monoclonal antibody $\bullet$ oxygenation index $\bullet$ histopathology $\bullet$ proliferating cell nuclear antigen
\end{abstract}

\section{Introduction}

Bronchopulmonary dysplasia (BPD), ${ }^{1}$ a chronic inflammatory lung disease of premature infants (1), remains a major problem in pediatric medicine, paradoxically due to success in improving survival of preterm infants now that respiratory distress syndrome is routinely treated with prenatal glucocorticoids and surfactant replacement therapy (2). It is estimated that $20 \%$ of ventilated newborns develop BPD (3), representing at least 3,000 infants annually in the USA (4). In particular,

Address correspondence to Mary E. Sunday, Department of Pathology, Brigham \& Women's Hospital, 75 Francis Street, Boston, MA 02115. Phone: 617-355-8402; FAX: 617-738-7041.

Received for publication 21 November 1997 and accepted in revised form 11 June 1998.

1. Abbreviations used in this paper: $125-\mathrm{d} / \mathrm{PRN}, 125-\mathrm{d}$ gestation/nonhyperoxic/surfactant-requiring baboon model of bronchopulmonary dysplasia (BPD); $140-d / 100 \% \mathrm{O}_{2}, 140-\mathrm{d}$ gestation hyperoxic baboon model of severe BPD; 140-d/PRN, 140-d gestation non-BPD control baboon; BLP, bombesin-like peptide; OI, oxygenation index; PCNA, proliferating cell nuclear antigen; RDS, respiratory distress syndrome.

The Journal of Clinical Investigation

Volume 102, Number 3, August 1998, 584-594

http://www.jci.org from 1976 to 1990, the incidence of BPD increased from $\sim 10$ to $33 \%$ in very low birth weight infants $(1,500$ grams or less). As a result, BPD now accounts for the highest mean health care costs per child and also is second only to asthma in terms of total health care costs per year in a given population (5). However, this increase in BPD is not explained simply by the decrease in acute mortality in this population (2). The pathophysiology of BPD is believed to be multifactorial, with factors contributing to lung injury believed to be trauma from mechanical ventilation, oxygen toxicity, infection, inflammation, and immaturity (4). Improvements in medical management, especially high frequency ventilation, positive pressure ventilation using nasal prongs, surfactant replacement therapy, lower administered $\mathrm{F}_{\mathrm{i}} \mathrm{O}_{2} \mathrm{~s}$, and careful monitoring and prompt treatment of infections, have reduced the severity of BPD occurring in human infants over the past decade $(2,4,6,7)$. Although prenatal maturational therapy with dexamethasone, with or without postnatal surfactant therapy, has slightly lowered the overall incidence of BPD, it is controversial as to whether surfactant deficiency per se is a contributing factor (8, 9). High dose surfactant alone has been found to have a more prolonged beneficial effect on oxygenation, with subsequent reduction in the incidence of BPD (10). Beneficial effects of postnatal dexamethasone on BPD are likely to be due to generalized antiinflammatory effects of glucocorticoids. However, in spite of all of these advances, there is no biological marker for identifying which very low birth weight infants will go on to develop chronic lung disease (11).

Recently, BPD has been clinically defined as oxygen dependence at $28 \mathrm{~d}$ postnatal age or $36 \mathrm{wk}$ after conception age, so we cannot draw exact parallels between the 6- to 10-d baboon model and the human disease. Nonetheless, there are close similarities in the apparent disease processes. In human hyaline membrane disease, numbers of cells containing pulmonary bombesin-like peptide (BLP) are low, due to either degranulation of NE cells and/or generalized epithelial cell necrosis. In lung sections from one of four infants with hyaline membrane disease, we previously detected marked elevation in BLP mRNA using in situ hybridization, suggesting that BLP might be implicated in the earliest stages of development of BPD (12). Pulmonary NE cell hyperplasia, which represents predominantly a cell differentiation response (13), occurs frequently in infants progressing to BPD $(14,15)$. This observation could be relevant to the pathophysiology of BPD because BLP are known to be potent bronchoconstrictor peptides as well as growth factors for pulmonary fibroblasts and epithelial cells. Thus, early overproduction of BLP could mediate the peribronchiolar and interstitial fibrosis and reactive airways disease which are hallmarks of BPD. Although definitive testing of this hypothesis will require a clinical investigation, valuable insight can be gained from relevant animal models. 
Although many species of rodents, nonhuman primates, and other laboratory animals develop acute hyaline membrane disease (HMD) (16-22) and even chronic interstitial lung disease similar to BPD (23-25), preterm baboons comprise the best nonhuman animal model for both HMD and its chronic sequelae, which appears clinically and pathologically most similar to human BPD (26-31). The increasing incidence of BPD as one of the major unsolved problems in pediatric medicine resulted in the initiation of a collaborative program by the $\mathrm{Na}$ tional Institutes of Health whereby the baboon model of BPD established by Coalson et al. in San Antonio has been targeted as a key tool in investigating this illness. Preterm animals delivered by Caesarean section at $140 \mathrm{~d}$ gestation $($ term $=180 \mathrm{~d}$ ) and maintained on $100 \% \mathrm{O}_{2}\left(140-\mathrm{d} / 100 \% \mathrm{O}_{2}\right)$ for $10 \mathrm{~d}$ (without surfactant replacement therapy) develop clinical and pathological features typical of moderate to severe BPD ("old BPD") similar to those described by Northway in 1967 (1). In brief, these changes include: severe distortion of lung architecture with segments of atelectasis and mucous plugging alternating with gross overexpansion of adjacent lung segments (compensatory emphysema), generalized decreased alveolarization, interstitial and peribronchiolar fibrosis, epithelial hyperplasia and squamous metaplasia, and smooth muscle hypertrophy with associated chronic reactive airways disease. In contrast, control 140-d gestation preterm baboons maintained for $10 \mathrm{~d}$ on oxygen PRN (to keep arterial blood hemoglobin above $\sim 90 \% \mathrm{O}_{2}$ saturation [140-d/PRN]) do develop acute respiratory distress syndrome (RDS) with hyaline membrane disease between 1 and $48 \mathrm{~h}$ after delivery, but recover from the acute injury and do not develop subsequent clinical or pathological changes reminiscent of BPD. More recently, Coalson et al. have developed a model of milder BPD occurring in extremely premature baboons (125 d gestation) receiving $\mathrm{O}_{2}$ PRN and requiring exogenous surfactant to survive, which is much more similar to the version of BPD currently seen in human infants (32). In this model of "new BPD," > $90 \%$ of 125 $\mathrm{d} / \mathrm{PRN}$ animals develop characteristic clinical and pathological features of chronic lung disease found in ventilated extremely low birth weight human infants: mild interstitial and peribronchiolar fibrosis, chronic reactive airways disease, and especially arrested alveolar septation (31).

Because infants with BPD have increased pulmonary NE cells containing BLP, a growth factor and bronchoconstrictor (15), we hypothesized that BLP mediates lung injury in BPD. The kinetics of BLP mRNA and peptide levels in normal baboon lung are similar to those in humans (Sunday, M.E., and R.L. Emanuel, manuscript in preparation). The present study demonstrates that urine BLP double between 24 and $72 \mathrm{~h}$ after birth in BPD animals, but not in controls. The severity of chronic lung disease correlates directly with this early increment in urine BLP. Blocking anti-BLP antibody administered to five BPD baboons soon after birth protects against histopathological changes of BPD. Although two of these baboons became septic, the others were clinically near normal. These observations suggest that elevated urine BLP might predict infants at highest risk for developing BPD, and blocking BLP after birth could be a novel treatment for preventing BPD.

\section{Methods}

Animals. The National Research Council Guide for the Care and Use of Laboratory Animals was strictly adhered to throughout all phases of this study. The Animal Care Committee of the Southwest Foundation for Biomedical Research reviewed and approved the protocols used in this study. Details of the neonatal intensive care unit (NICU) animal care have been described previously (29). Values from clinical monitoring at 1-2 $\mathrm{h}$ intervals were used for the calculation of mean oxygenation indices \pm SE $\left[\mathrm{OI}=\left(\mathrm{F}_{\mathrm{i}} \mathrm{O}_{2} \times\right.\right.$ mean airway pressure) $\times 100 / \mathrm{P}_{\mathrm{a}} \mathrm{O}_{2}$ ] for three groups of experimental animals between birth and $10 \mathrm{~d}$ of age: 140-d/PRN $\left(\mathrm{O}_{2} \mathrm{PRN}\right.$, non-BPD); 140-d/ $100 \% \mathrm{O}_{2}$ without antibody treatment $\left(100 \% \mathrm{O}_{2} / \mathrm{Neg}\right.$, severe $\left.\mathrm{BPD}\right)$; and $140-\mathrm{d} / 100 \% \mathrm{O} 2$ receiving intravenous anti-BLP blocking antibody treatment $\left(100 \% \mathrm{O}_{2} / 2 \mathrm{~A} 11\right)$. 2A11 murine monoclonal antibody $(1 \mathrm{mg} / \mathrm{ml}$, sterile, pyrogen-free, and azide-free) was administered intravenously as an infusion starting $2 \mathrm{~h}$ after birth $(5 \mathrm{mg} / \mathrm{kg}$, given over $2 \mathrm{~h}$ ), with two boosts given similarly on days 3 and $6(4 \mathrm{mg} / \mathrm{kg}$, starting at $\sim 72$ and 144 hours).

Urine BLP RIA. Urine was collected from newborn baboons as 24-h pooled specimens $(5-50 \mathrm{ml}$ total volume) which was stored at $-70^{\circ} \mathrm{C}$, shipped frozen on dry ice, and thawed only once at the time of assay, using an aliquot $(\sim 1 \mathrm{ml})$ for RIA.

BLP levels were quantitated by RIA (Inc Star Corp., Stillwater, $\mathrm{MN}$ ) using the clear supernatant of urine samples, containing $25 \mathrm{mM}$ acetic acid and stored at $-70^{\circ} \mathrm{C}$. The assay uses a rabbit antibody to amphibian bombesin, has a detection limit of $100 \mathrm{pg} / \mathrm{ml}$, and detects bombesin and its mammalian homologue gastrin-releasing peptide (GRP) which is the major known pulmonary BLP (12), but not related neuropeptides neuromedin B, substance P, nor neurotensin. Each sample was measured in at least two separate radioimmunoassays. Urine BLP values were normalized to their respective creatinine content $(\mathrm{mg} /$ $\mathrm{ml}$ ) which was measured using a kit (Sigma Chemical Co., St. Louis, $\mathrm{MO})$ to correct for variations in urinary concentration or dilution. Each value shown on the plots represents a 24-h urine collection ending at the indicated time points; the normalized value for the first day urine collection is defined as $100 \%$, with subsequent values expressed as the mean percent change compare to the 24-h urine BLP level.

Histopathological and immunohistochemical analyses. Tissues were fixed in $4 \%$ paraformaldehyde for 18 to $24 \mathrm{~h}$ before routine processing into paraffin, as described previously (33). Histochemical stains included hematoxylin and eosin for general tissue architecture, Masson's trichrome for fibrosis, and elastin stain for demonstrating pulmonary alveolar architecture (34).

Routine immunostaining was carried out on $3-\mu \mathrm{m}$ sections as described previously using PCNA monoclonal antibody clone PC10 (1:20 dilution) (Dako Corp., Carpinteria, CA) (33), our own rabbit antibombesin antisera (1:500 dilution) (35), or rabbit polyclonal antiPGP 9.5 (1:500 dilution) (Ultraclone Inc., Isle of Wight, UK) with the avidin-biotin complex (ABC) technique (Vector Laboratories, Burlingame, CA) (33). The peroxidase substrate was diaminobenzidine and methyl green was used as the counterstain. Negative controls run in parallel consisted of the following: for PCNA, the isotype-matched MOPC-21 (IgG1) (Sigma Chemical Co.) was used; and for antibombesin antisera, bombesin antiserum preabsorbed overnight with bombesin antigen $(10 \mu \mathrm{g} / \mathrm{ml})(36)$.

Localization of 2A11 mouse monoclonal antibody in baboon tissues was carried out using a 1:10 dilution of biotinylated horse antimouse IgG (Vector Laboratories) as the primary antibody or biotinylated normal horse $\mathrm{IgG}$ as the negative control incubated overnight at $4^{\circ} \mathrm{C}$. Subsequent incubations with methanol/ $\mathrm{H}_{2} \mathrm{O}_{2}$, the $\mathrm{ABC}$ reagent, and biotinylated tyramide (Tyramide-System Amplification [TSA] from Dupont-New England Nuclear, Boston, MA) were the same as for the standard immunoperoxidase method.

Statistical analyses. For group comparisons, statistical analyses used the Student's $t$ test (unpaired), one-way ANOVA, or two-way ANOVA and results are given as mean values \pm SE.

\section{Results}

Changes in urine BLP levels predict BPD. Results of urine bombesin-like peptide (BLP) radioimmunoassay, normalized 

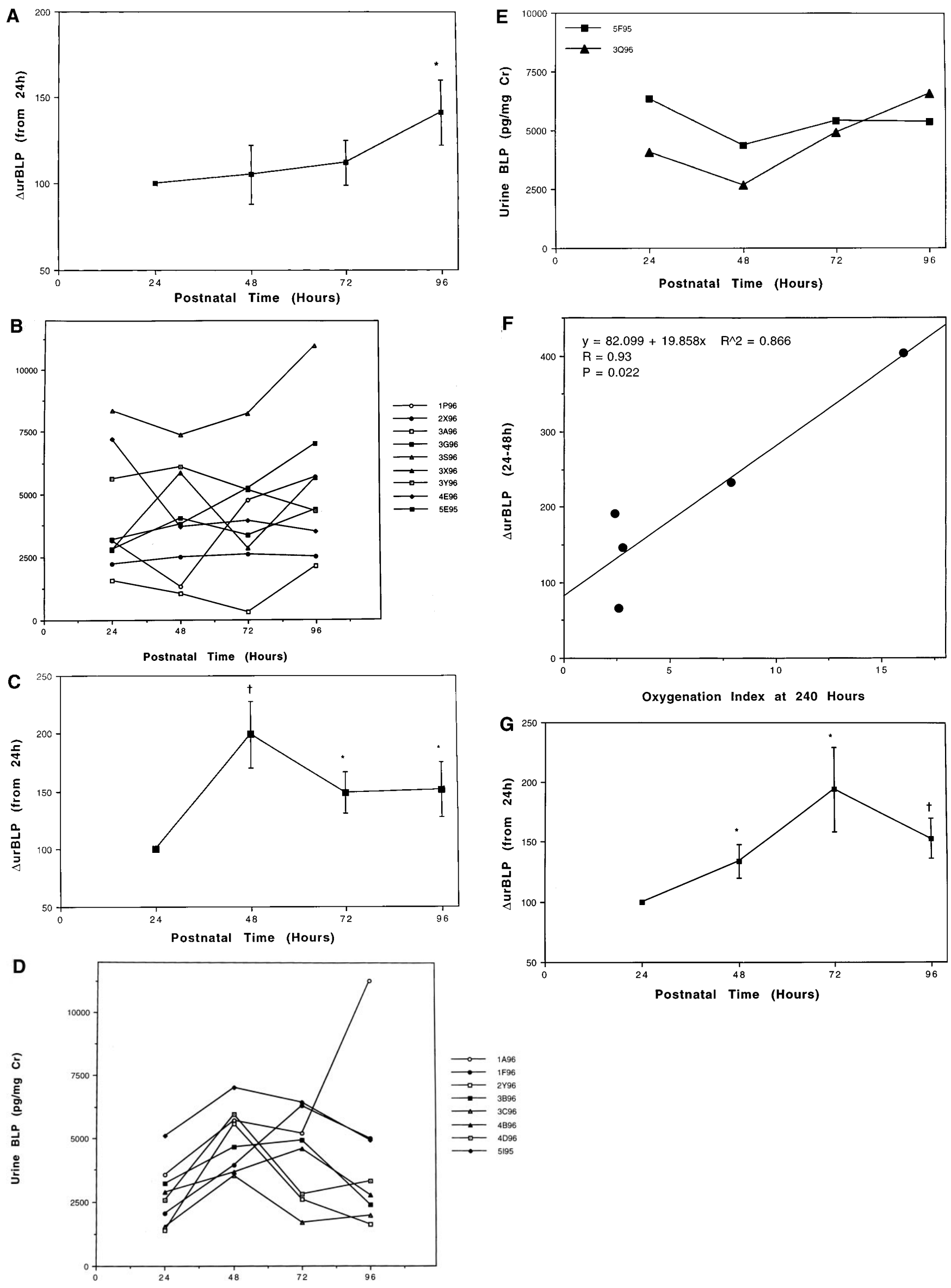
for creatinine to correct for variations in urinary concentration or dilution, are given in Fig. 1. Control animals (140-d/PRN) had no significant change in mean urine BLP levels between 24 and $72 \mathrm{~h}$ after delivery $(n=9)$. Mild elevation in urine BLP levels occurred after $\geq 96 \mathrm{~h}$, consistent with increased numbers of pulmonary NE cells after prolonged mechanical ventilation (14). Individual values from all nine animals are shown in Fig. $1 \mathrm{~B}$, with all animals manifesting either a decline or minimal increase between 24 and $72 \mathrm{~h}$ after birth.

In contrast, the group of $140-\mathrm{d} / 100 \% \mathrm{O}_{2}$ baboons $(n=8)$ developing chronic lung disease similar to the original severe form of BPD had a significant doubling in mean urine BLP levels between 24 and $48 \mathrm{~h}$, termed $\Delta$ urBLP (24-48) (Fig. $1 C$ ). All of these animals manifested moderate to severe oxygenation impairment (oxygenation index $[\mathrm{OI}]>2.5$ ) and chest $\mathrm{x}$-ray changes at 6 to $10 \mathrm{~d}$ of age, where OI is defined as $\left(\mathrm{F}_{\mathrm{i}} \mathrm{O}_{2} \times\right.$ mean airway pressure $) \times 100 / \mathrm{P}_{\mathrm{a}} \mathrm{O}_{2}$. Although peaking at $48 \mathrm{~h}$, urine BLP levels were still significantly elevated above the $24-\mathrm{h}$ values at 72 and $96 \mathrm{~h}$. Individual results from all eight of these animals are given in Fig. $1 \mathrm{D}$. A small percentage ( 15-20\%) of 140-d animals treated with $100 \% \mathrm{O}_{2}$ do not develop significant clinical evidence of chronic lung disease during their course. Urine BLP levels from two such animals are shown in Fig. $1 E$ : both of these baboons had a decline rather than an increase in urine BLP levels (with 48 h levels representing 66 and $58 \%$ of the corresponding $24-\mathrm{h}$ values).

In the five $140-\mathrm{d}$ animals treated with $100 \% \mathrm{O}_{2}$ for which serial urine collections were available, there was a direct correlation $(r=0.93, P=0.022)$ between the increment in urine BLP between 24 and $48 \mathrm{~h}$ and the OI at $10 \mathrm{~d}$ (Fig. $1 F$ ). There was no correlation between early changes in urine BLP (or absolute values of urine BLP at $24,48,72$, or $96 \mathrm{~h}$ ) and OI between 2 and $216 \mathrm{~h}$ of age (data not shown). In the $140-\mathrm{d} / 100 \%$ $\mathrm{O}_{2}$ model, we did not observe any correlations between absolute urine BLP levels and OI, apparently due to variability in baseline urine BLP levels.

The above observations are based on the hyperoxic baboon model, and we cannot be absolutely certain that increased urinary BLP does not reflect increased BLP gene expression in response to hyperoxia rather than as a result of BPD per se. To provide assessment of changes in urine BLP and BPD independently of therapy with $100 \% \mathrm{O}_{2}$, we also measured urine BLP levels in the second baboon model of "new BPD" (125-d gestation baboons treated with $\mathrm{O}_{2}$ PRN and exogenous surfactant therapy) (30). In this group $(n=12)$, there was a significant $(\sim 30 \%)$ increase in urine BLP between 24 and $48 \mathrm{~h}$ after birth (Fig. $1 \mathrm{G}$ ), with doubling occurring at $72 \mathrm{~h}$; levels remained elevated at $96 \mathrm{~h}$. Most of these 125-d animals were maintained for only $6 \mathrm{~d}(n=11)$, so that we could not analyze correlations with $10-\mathrm{d}$ OI values. These observations suggest that elevated urine BLP levels might be associated with chronic lung disease occurring in diverse clinical settings.

In addition to its presence in lung, GRP mRNA can be detected in baboon brain, thyroid, stomach, and pancreas at $140 \mathrm{~d}$ gestation and after $100 \% \mathrm{O}_{2}$ treatment for $10 \mathrm{~d}$ (two animals screened, data not shown). It was also detected in thymus and/or adrenal in the two animals given $100 \% \mathrm{O}_{2}$ treatment for $10 \mathrm{~d}$. Using reverse transcriptase-PCR (RT-PCR), we did not detect GRP mRNA in kidney or bladder. In previous studies of human fetal tissues, the major source of GRP mRNA and BLP immunoreactivity has been demonstrated to be lung (12). We have obtained total RNA samples from lung of one 140-d animal given $\mathrm{O}_{2}$ PRN for $24 \mathrm{~h}$ and another animal given $100 \%$ $\mathrm{O}_{2}$ treatment for $24 \mathrm{~h}$ (thanks to Dr. Carl White, National Jewish Medical and Reaserch Center, Denver, CO). The animal treated with $100 \% \mathrm{O}_{2}$ had about a twofold increase in lung levels of GRP mRNA as compared to the PRN animal (data not shown). When we calculate the amount of BLP excreted in a 24-h urine collection $(\sim 5 \mathrm{ng})$, it is less than half of the BLP content of lung tissue harvested from animals following $100 \%$ $\mathrm{O}_{2}$ treatment for $10 \mathrm{~d}(\sim 14 \mathrm{ng})$. Thus, although we cannot be certain that the lung is the only source of urine BLP, the cumulative data are consistent with lung as the major contributor to urine BLP levels.

Postnatal treatment with anti-BLP-blocking antibody. To test whether BLP might play a causative role in the pathophysiology of BPD, we administered the well-characterized murine monoclonal anti-BLP-blocking antibody 2 A11 to five $140-d /$

\footnotetext{
Figure 1. Urine BLP kinetics in preterm baboons without and with BPD. BLP levels in 24-h urine collections were quantitated by radioimmunoassay and normalized to their respective creatinine content $(\mathrm{mg} / \mathrm{ml})$ as detailed in Methods. Each value shown on the plot represents a 24-h urine collection ending at the indicated time points; the normalized value for the first day urine collection is defined as $100 \%$, with subsequent values expressed as the mean percent change compared to the 24-h urine BLP level. For group comparisons, statistical analyses used the Student's $t$ test (unpaired) and results are given as mean values \pm SEM. ( $A$ and $B)$ No BPD control baboons, delivered by C-section after $140 \mathrm{~d}$ gestation (term $=180 \mathrm{~d}$ ) and maintained on sufficient oxygen to keep arterial $\mathrm{O}_{2}$ saturation above $90 \%\left[140 \mathrm{~d} / \mathrm{O}_{2}\right.$ PRN]. $(A)$ Mean urine BLP levels do not change between the 24- and 72-h collections $(n=9)$. (B) Individual absolute values of urine BLP (pg/mg creatinine) from all control animals. $(C-F)$ Baboons delivered after 140 d gestation and maintained on $100 \% \mathrm{O}_{2}$, develop clinical and pathological features typical of moderate to severe BPD after $10 \mathrm{~d}$ of life. $(C)$ Mean percent change in urine BLP levels from animals which developed moderate to severe BPD. There is a significant doubling in mean BLP levels between the 24- and 48-h urine collections $(n=8)$. All of these animals manifested moderate to severe oxygenation impairment and chest x-ray interstitial changes at $10 \mathrm{~d}$ of age. Although peaking at $48 \mathrm{~h}$, urine BLP levels were still significantly elevated above the 24-h values at 72 and $96 \mathrm{~h}$. (D) Individual absolute values of urine BLP (pg/mg creatinine) from all animals which developed moderate to severe BPD. $(E)$ A small percentage $(\sim 15-20 \%)$ of $140-\mathrm{d}$ animals treated with $100 \% \mathrm{O}_{2}$ did not develop any evidence of chronic lung disease during the 10-d treatment course. Urine BLP levels from two such animals are given in $E$, both of which had a decline rather than an increase in urine BLP levels (with 48-h levels representing 66 and 58\% of the corresponding 24-h values). ( $F$ ) A plot of urine BLP (percentage change from 24 to $48 \mathrm{~h}$ ) versus OI at $10 \mathrm{~d}$ reveals a direct correlation in 140-d animals treated with $100 \% \mathrm{O}_{2}(r=0.93, P=0.022, n=5)$. $(G) \mathrm{Ba}$ boons delivered after $125 \mathrm{~d}$ gestation and maintained on $\mathrm{PRN}_{2}$, develop clinical and pathological features typical of mild BPD after $14 \mathrm{~d}$ of life. To clarify whether the changes in $140 \mathrm{~d} / 100 \% \mathrm{O}_{2}$ animals might be caused by $100 \% \mathrm{O}_{2}$ toxicity or rather might be associated with changes specific to BPD per se, we also measured urine BLP levels in $125 \mathrm{~d}$ gestation baboons treated with $\mathrm{O}_{2}$ PRN, all of which require treatment with exogenous surfactant for survival. Over $95 \%$ of these extremely premature animals develop clinical and radiological evidence of mild BPD after $14 \mathrm{~d}$ of treatment. $(G)$ Mean urine BLP levels from animals which develop mild BPD demonstrate a significant $(\sim 30 \%)$ increase in mean BLP levels between the 24- and 48-h urine collections, and a doubling by $72 \mathrm{~h}(n=12)$.
} 
$100 \% \mathrm{O}_{2}$ baboons beginning $2 \mathrm{~h}$ after birth. The dosage and frequency of administration were based on results from previous preclinical pharmacokinetics studies in mice and dogs (37): we chose a dose comparable to that required for $>95 \%$ block- ing of BLP-triggered gastrin release in dogs. We sought objective evidence that $2 \mathrm{~A} 11$ was indeed functioning as a BLP blocking antibody in the preterm baboons. First, the five 140$\mathrm{d} / 100 \% \mathrm{O}_{2}$ animals receiving $2 \mathrm{~A} 11$ demonstrated only slightly
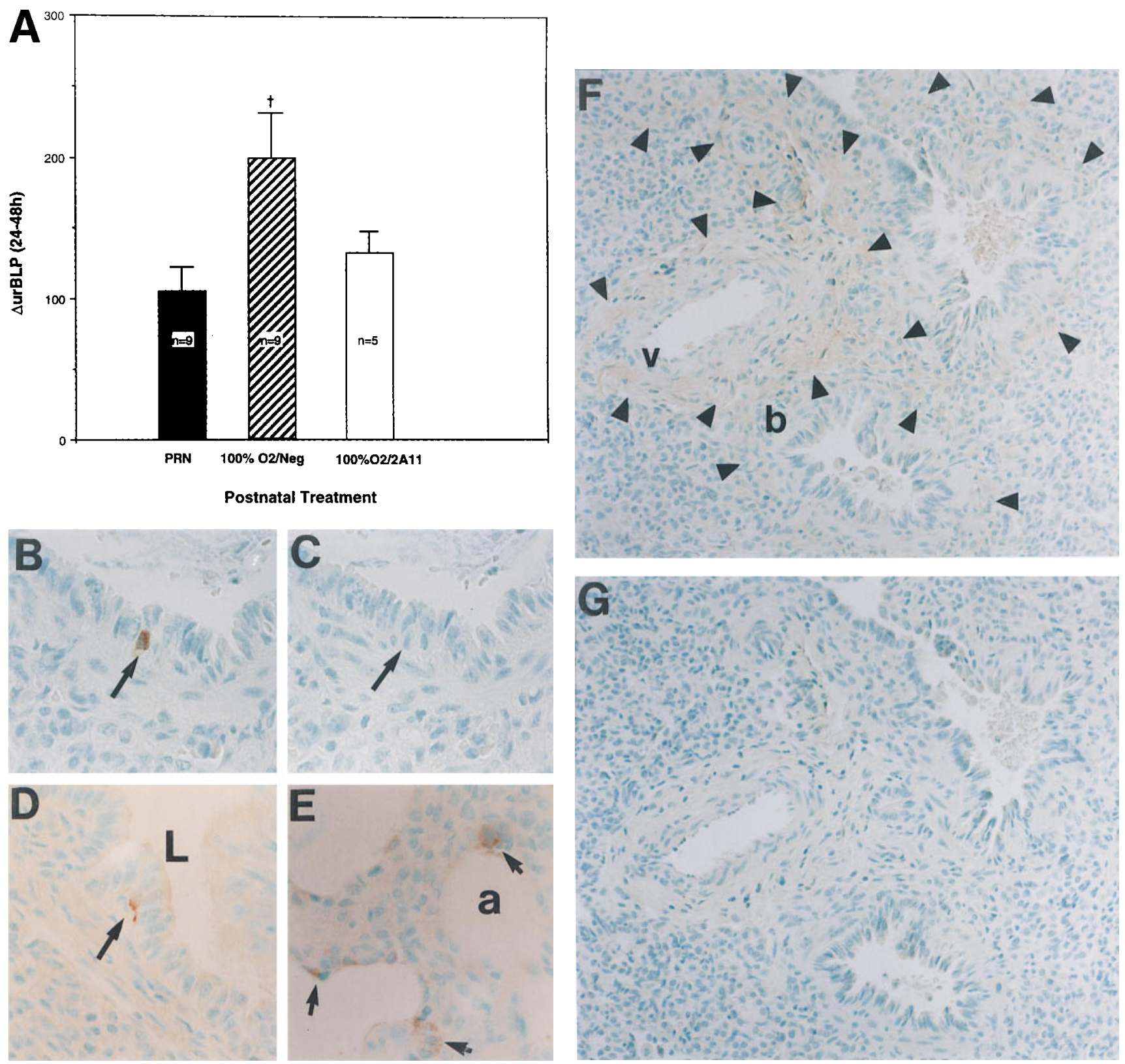

Figure 2. 140-d baboons treated with $100 \% \mathrm{O}_{2}$ and anti-BLP antibody (2A11). ( $A$ ) The change in urine BLP from 24 to $48 \mathrm{~h}$ in non-BPD $140-\mathrm{d} /$ PRN baboons $(P R N, n=9), 140-\mathrm{d} / 100 \% \mathrm{O}_{2}$ baboons with severe BPD that did not receive antibody treatment $\left(100 \% \mathrm{O}_{2} / \mathrm{Neg}, n=8\right)$, and the five $140-\mathrm{d} / 100 \% \mathrm{O}_{2}$ baboons that received $2 \mathrm{~A} 11$ shortly after birth $\left(100 \% \mathrm{O}_{2} / 2 \mathrm{Al1}\right)$. Only the non-2A11-treated animals exposed to $100 \% \mathrm{O}_{2}$ had a significant increase in urine BLP at $48 \mathrm{~h}$. Results are given as mean values \pm SE $\left({ }^{\dagger} P<0.001\right.$ compared to $140-\mathrm{d} / \mathrm{PRN}$ controls using the Student's $t$ test, unpaired). (B-E) Lung sections from representative 2A11-treated animals demonstrate BLP-positive cells. (B) BLP immunostaining of a section of lung tissue from a 2A11-treated animal (4N96) demonstrates a small cluster of pulmonary NE cells in a bronchiole. (C) A thin section immediately serial to $(B)$ run in parallel using antibombesin antiserum preabsorbed with bombesin antigen $(10 \mu \mathrm{g} / \mathrm{ml})$ demonstrates loss of immunostaining of the same NE cells. ( $B-E$ : magnification of 100 , methyl green counterstain). ( $D$ and $E$ ) There are frequent BLP-positive cells present in the small bronchioles $(D)$ and alveolar ducts $(E$, arrows); these cells also contain the NE-specific marker PGP 9.5 (data not shown). All immunostaining was carried out as detailed in Methods using 3- $\mu \mathrm{m}$ thick lung sections and our own rabbit antibombesin antiserum (1:500) with the ABC-complex immunoperoxidase technique. The substrate was diaminobenzidine (33). (Magnification of 80, methyl green counterstain). $(F)$ Horse anti-mouse IgG immunostaining of lung tissue sections from a representative 2A11-treated animal demonstrates staining for 2A11 (murine $\mathrm{IgG}$ ) in the undifferentiated mesenchymal tissue around developing blood vessels and airways (between arrows), but not in differentiated smooth muscle around blood vessels $(v)$ or bronchioles $(b)$. $(G)$ A section immediately serial to $(F)$ incubated in parallel with normal horse serum lacks this mesenchymal immunostaining. 

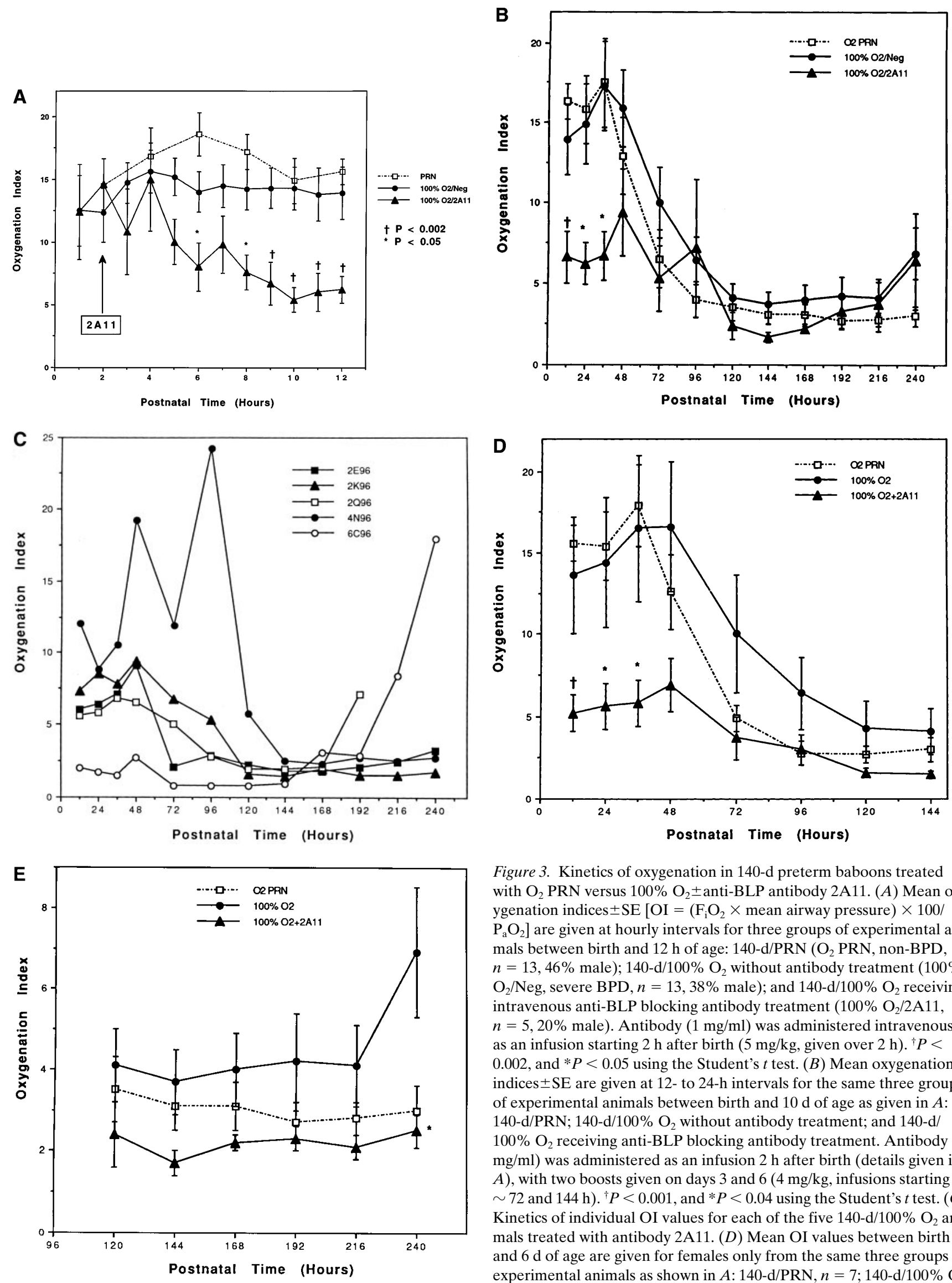

Figure 3. Kinetics of oxygenation in 140-d preterm baboons treated with $\mathrm{O}_{2}$ PRN versus $100 \% \mathrm{O}_{2} \pm$ anti-BLP antibody $2 \mathrm{~A} 11$. $(A)$ Mean oxygenation indices \pm SE $\left[\mathrm{OI}=\left(\mathrm{F}_{\mathrm{i}} \mathrm{O}_{2} \times\right.\right.$ mean airway pressure $) \times 100 /$ $\mathrm{P}_{\mathrm{a}} \mathrm{O}_{2}$ ] are given at hourly intervals for three groups of experimental animals between birth and $12 \mathrm{~h}$ of age: $140-\mathrm{d} / \mathrm{PRN}\left(\mathrm{O}_{2} \mathrm{PRN}\right.$, non-BPD, $n=13,46 \%$ male); $140-\mathrm{d} / 100 \% \mathrm{O}_{2}$ without antibody treatment $(100 \%$ $\mathrm{O}_{2} / \mathrm{Neg}$, severe BPD, $n=13,38 \%$ male); and $140-\mathrm{d} / 100 \% \mathrm{O}_{2}$ receiving intravenous anti-BLP blocking antibody treatment $\left(100 \% \mathrm{O}_{2} / 2 \mathrm{~A} 11\right.$, $n=5,20 \%$ male $)$. Antibody $(1 \mathrm{mg} / \mathrm{ml})$ was administered intravenously as an infusion starting $2 \mathrm{~h}$ after birth $(5 \mathrm{mg} / \mathrm{kg}$, given over $2 \mathrm{~h}) .{ }^{\dagger} P<$ 0.002 , and $* P<0.05$ using the Student's $t$ test. $(B)$ Mean oxygenation indices $\pm \mathrm{SE}$ are given at 12 - to 24 -h intervals for the same three groups of experimental animals between birth and $10 \mathrm{~d}$ of age as given in $A$ : 140-d/PRN; $140-\mathrm{d} / 100 \% \mathrm{O}_{2}$ without antibody treatment; and 140-d/ $100 \% \mathrm{O}_{2}$ receiving anti-BLP blocking antibody treatment. Antibody (1 $\mathrm{mg} / \mathrm{ml}$ ) was administered as an infusion $2 \mathrm{~h}$ after birth (details given in $A$ ), with two boosts given on days 3 and $6(4 \mathrm{mg} / \mathrm{kg}$, infusions starting at $\sim 72$ and $144 \mathrm{~h}) .{ }^{\dagger} P<0.001$, and ${ }^{*} P<0.04$ using the Student's $t$ test. $(C)$ Kinetics of individual OI values for each of the five $140-\mathrm{d} / 100 \% \mathrm{O}_{2}$ animals treated with antibody 2A11. (D) Mean OI values between birth and $6 \mathrm{~d}$ of age are given for females only from the same three groups of experimental animals as shown in $A: 140-\mathrm{d} / \mathrm{PRN}, n=7 ; 140-\mathrm{d} / 100 \% \mathrm{O}_{2} /$ Neg, $n=8$; and $140-\mathrm{d} / 100 \% \mathrm{O}_{2} / 2 \mathrm{~A} 11, n=4 .{ }^{\dagger} P<0.001$, and ${ }^{*} P<0.02$ using the Student's $t$ test. $(E)$ Mean OI values between 5 and $10 \mathrm{~d}$ of age are given only for animals without clinical evidence of septicemia: $140-\mathrm{d} / \mathrm{PRN}, n=13 ; 140-\mathrm{d} / 100 \% \mathrm{O}_{2} / \mathrm{Neg}, n=13$; and $140-\mathrm{d} / 100 \% \mathrm{O}_{2} / 2 \mathrm{~A} 11$, $n=3$. Comparison of $140-\mathrm{d} / 100 \% \mathrm{O}_{2} / \mathrm{Neg}$ and $140-\mathrm{d} / 100 \% \mathrm{O}_{2} / 2 \mathrm{~A} 11$ groups by one-way ANOVA yields $* P<0.001$. 
Table I. Clinical Profiles of 140-d Baboons Treated for $10 \mathrm{~d}$ with PRN $\mathrm{O}_{2}$ versus $100 \% \mathrm{O}_{2}$ with or without 2 A11 Treatment

\begin{tabular}{|c|c|c|c|c|c|c|c|}
\hline Treatment $(n)^{*}$ & $2 \mathrm{~A} 11^{*}$ & Birthweight (grams) $)^{\S}$ & $\%$ Malell & $\% \mathrm{HFOV}^{\mathbb{I I}}$ & $\%$ Air leak** & $\mathrm{OI}_{140^{\ddagger}}$ & $\operatorname{urBLP}(24-48 \mathrm{~h})^{\S \S}$ \\
\hline $\mathrm{O}_{2} \mathrm{PRN}(13)$ & No & $534 \pm 18$ & $38(5)$ & 54 & 31 & $3.0 \pm 0.6$ & $105 \pm 17(9)$ \\
\hline $100 \% \mathrm{O}_{2}(13)$ & No & $527 \pm 14$ & $46(6)$ & 46 & 31 & $6.9 \pm 1.6$ & $199 \pm 29|| \mid(9)$ \\
\hline $100 \% \mathrm{O}_{2}(5)$ & Yes & $498 \pm 6$ & $20(1)$ & 0 & 0 & $2.5 \pm 0.4^{\mathrm{qIT}}$ & $132 \pm 13(5)$ \\
\hline
\end{tabular}

Clinical parameters relevant to the medical status of preterm infants are given. *The number of animals in each treatment group is given in parentheses. ${ }^{*}$ Whether or not animals were given $2 \mathrm{~A} 11$ intravenously beginning $2 \mathrm{~h}$ after birth is indicated. ${ }^{\S}$ Birthweight is given in grams \pm SEM. $\|$ The percentage of male animals in each group is given, with the total number of males given in parentheses. ${ }^{\mathrm{T}}$ The percentage of animals requiring high frequency ventilation is given. ${ }^{* *}$ The percentage of animals developing clinical evidence of pneumothorax, requiring chest tube insertion, is given. ${ }^{\ddagger}$ Oxygenation Index $(O I)$ at $240 \mathrm{~h}$ is given \pm SEM. ${ }^{\text {qII } P}<0.001$ compared to $100 \% \mathrm{O}_{2}$ positive controls (one-way ANOVA). ${ }^{\$ 8}$ The change in urine BLP (normalized for creatinine) from 24 to $48 \mathrm{~h}$ is given. Urine specimens were not available on all animals. The number of animals analyzed is given in parentheses. $\| I P=0.006$ compared to PRN negative controls $(t$ test $)$.

elevated urine BLP at $48 \mathrm{~h}$, which was not statistically significant compared to the 140-d/PRN controls; in contrast, 140-d/ $100 \% \mathrm{O}_{2}$ baboons which did not receive $2 \mathrm{~A} 11$ had a significant doubling of urine BLP at $48 \mathrm{~h}$ (Fig. $2 \mathrm{~A}$ ). Results of BLP immunostaining of lung tissue sections from the five 2A11treated baboons were similar to $140-\mathrm{d} / 100 \% \mathrm{O}_{2}$ animals which did not receive antibody (Fig. 2, $B-E$ ): most BLP-positive neuroendocrine (NE) cells were localized to bronchioles (Fig. 2, $B$ and $D$ ) and alveolar ducts (Fig. $2 E$ ). Specific immunostaining in thin serial sections was abrogated by preabsorption of antibody with bombesin antigen (Fig. $2 \mathrm{C}$ ). Immunohistochemical analyses of postmortem tissue sections from all five 2A11treated baboons using biotinylated horse anti-mouse IgG demonstrated the presence of mouse $\mathrm{IgG}$ predominantly in loose undifferentiated mesenchymal tissue around developing blood vessels and airways (Fig. $2 F$ ). This pattern of immunostaining is not observed when biotinylated normal horse $\mathrm{IgG}$ (same purity and concentration) is substituted for the horse anti-mouse IgG (Fig. $2 G$ ). These observations indicate that 2A11 administered systemically reaches the developing lungs, which are known to be rich in endogenous BLP derived from pulmonary NE cells (Fig. 2, B-E) (15).

The mean oxygenation indices for the group of five 2A11treated baboons are given in Fig. 3 and Table I, which also summarize parallel data from the negative control (140-d/
PRN, $n=13)$ and positive control $\left(140-\mathrm{d} / 100 \% \mathrm{O}_{2}, n=13\right)$ groups. The most striking immediate effect of the 2A11 infusion given $2 \mathrm{~h}$ after birth is marked improvement in mean OI between birth and $12 \mathrm{~h}$ of age (Fig. $3 \mathrm{~A}$ ). The data in Fig. $3 \mathrm{~A}$ clearly demonstrate a significant improvement in mean OI between 4 and $6 \mathrm{~h}$ after beginning the 2A11 infusion. This improved OI seen with $2 \mathrm{~A} 11$ is sustained until $36 \mathrm{~h}$ of age (Fig. 3 $B$ ) compared to either $140-\mathrm{d} / \mathrm{PRN}$ or $140-\mathrm{d} / 100 \% \mathrm{O}_{2}$ animals, both of which develop acute respiratory distress syndrome similar to human hyaline membrane disease. Although there is also a trend towards improved OI at the 144-h time point, there is no significant difference in OI between the 2A11treated animals and the other groups at later time points when the entire pool of animals is used for analysis. However, none of the five 2A11 animals developed an air leak (pneumothorax), in contrast to 4 of $13140-\mathrm{d} / 100 \% \mathrm{O}_{2}$ "old BPD" positive controls (all female) and 4 of 13 140-d/PRN "no BPD" negative controls (two male, two female) (31\% each group, see Table I). Also, none of the $2 \mathrm{~A} 11$ animals required high frequency ventilation, in contrast to $46 \%$ of the $140-\mathrm{d} / 100 \% \mathrm{O}_{2}$ animals and $54 \%$ of the $140-\mathrm{d} / \mathrm{PRN}$ animals (Table I). All of these control animals $\left(100 \% \mathrm{O}_{2}\right.$ and PRN) were studied during the same time period as the 2A11-treated animals (1995-97), and therefore were subjected to the same intensive care unit procedures under the direction of a single neonatologist (Dr. Brad-

Figure 4. Histopathological analyses and PCNA immunostaining in lung tissues from 140-d baboons treated with $\mathrm{O}_{2} \mathrm{PRN}$ or $100 \% \mathrm{O}_{2} \pm 2 \mathrm{~A} 11$. $(A-D)$ Lung lobes were inflated with $4 \%$ paraformaldehyde $(A-C$ : elastic tissue stain, magnification of $8 ; D$ : hematoxylin and eosin, magnification of 80). Representative sections of lung tissue are shown from one animal for each group: $(A)$ A typical non-BPD 140-d/PRN control animal maintained for $10 \mathrm{~d}$. There is normal alveolarization and no evidence of fibrosis. (B) A 140-d/100\% $\mathrm{O}_{2}$ baboon with severe chronic lung disease after $10 \mathrm{~d}$ of treatment. There is extensive interstitial and peribronchiolar fibrosis with adjacent areas of compensatory emphysema and airway dilatation. $\left(C\right.$ and $D$ ) A $140-\mathrm{d} / 100 \% \mathrm{O}_{2}$ baboon receiving three doses of $2 \mathrm{~A} 11$ with $10 \mathrm{~d}$ of $100 \% \mathrm{O}_{2}$. There is minimal evidence of interstitial fibrosis (best appreciated with elastin stain in $C$ ), most of which occurs in areas with intraalveolar hemorrhage and/or resolving hyaline membrane disease $(C$, arrows). Although there is some evidence of airway and/or airspace dilatation, the magnitude of these changes is much less than that occurring in most animals not receiving 2A11. Pockets of alveolar hemorrhage and sparse neutrophilic infiltrates occur frequently in the vicinity of residual hyaline membranes (long arrows in $D$ indicate intraalveolar hyaline membranes; short arrow indicates hyaline membrane phagocytosed by an alveolar macrophage). Although there is some perivascular fibrosis ( $V$, arrow in $D)$, there is minimal to no evidence of peribronchiolar fibrosis (aw, airway lumen) ( $D$ : hematoxylin and eosin). ( $E-H)$ Immunostaining of noninflated lung tissue slices fixed for $18-24 \mathrm{~h}$ with $4 \%$ paraformaldehyde. $(E-G)$ PCNA immunostaining, carried out as described previously (33); $(H)$ MOPC IgG1 negative control: all magnification of 80. Representative sections of lung tissue are shown from one animal for each group, with representative positive cells indicated by arrows (short arrows, epithelial cells; arrowheads, mesenchymal cells). (E) A typical non-BPD 140-d/PRN control animal maintained for $10 \mathrm{~d}$. There is PCNA immunostaining localized predominantly to epithelial cells in airways and airspaces. $(F) \mathrm{A} 140-\mathrm{d} / 100 \% \mathrm{O}_{2}$ baboon with severe chronic lung disease after $10 \mathrm{~d}$ of treatment demonstrates extensive PCNA labeling of mesenchymal cells in the interstitium and peribronchiolar regions, coinciding with areas of fibrosis, and also intense PCNA labeling of epithelial cells in airways and airspaces. $(G$ and $H)$ A $140-\mathrm{d} / 100 \% \mathrm{O}_{2}$ baboon receiving three doses of $2 \mathrm{~A} 11$ with $10 \mathrm{~d}$ of $100 \% \mathrm{O}_{2}$. PCNA immunostaining is predominantly localized to the epithelial cells in airways and alveoli. There is much reduced PCNA immunostaining compared to either the $140-\mathrm{d} / \mathrm{PRN}$ animals (as in $E$ ) or the $140-\mathrm{d} / 100 \% \mathrm{O}_{2}$ animals (as in $F$ ). 
A 5 F

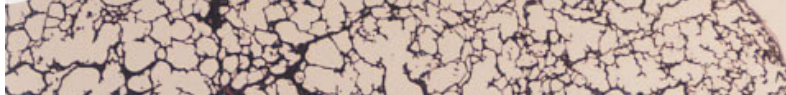

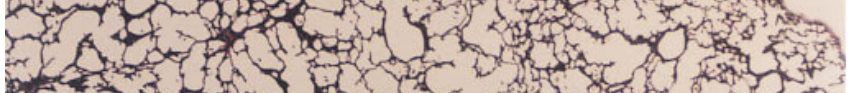

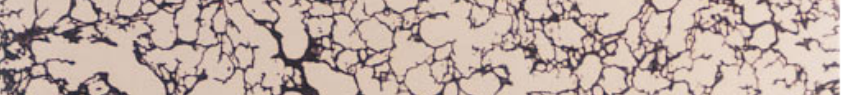

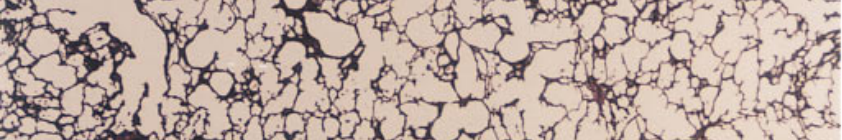

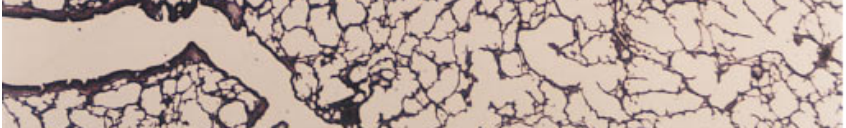
ER.

c

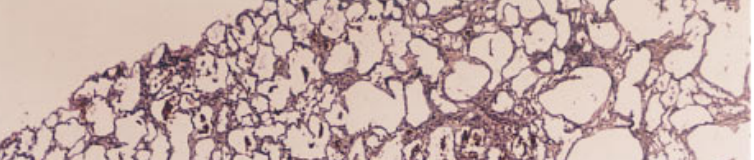
af

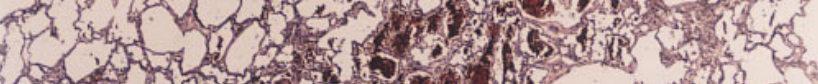
500 .

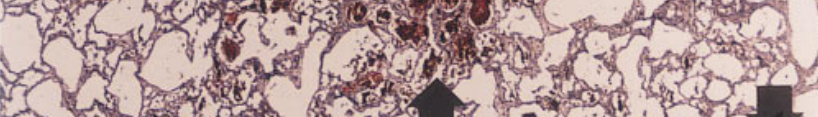

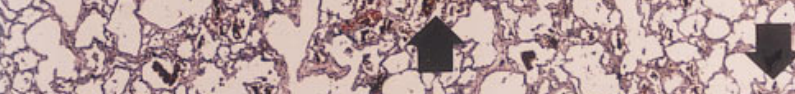

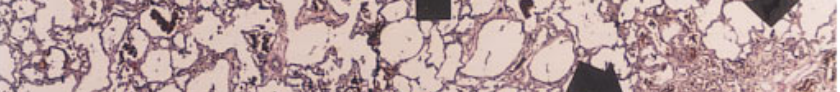

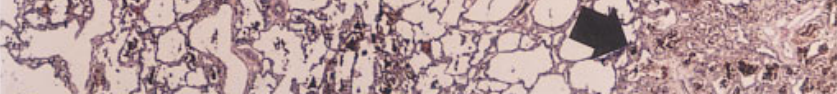

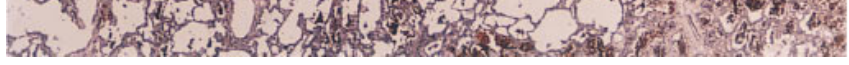
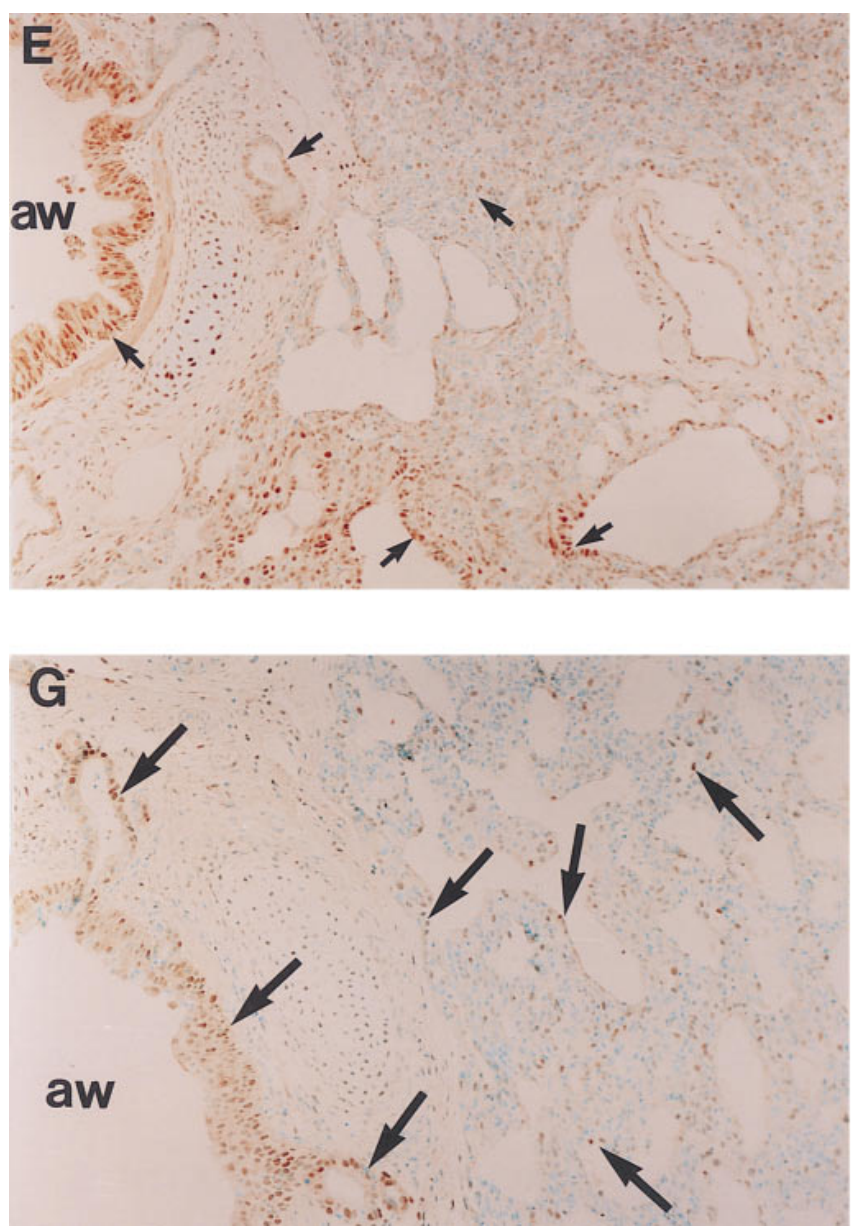
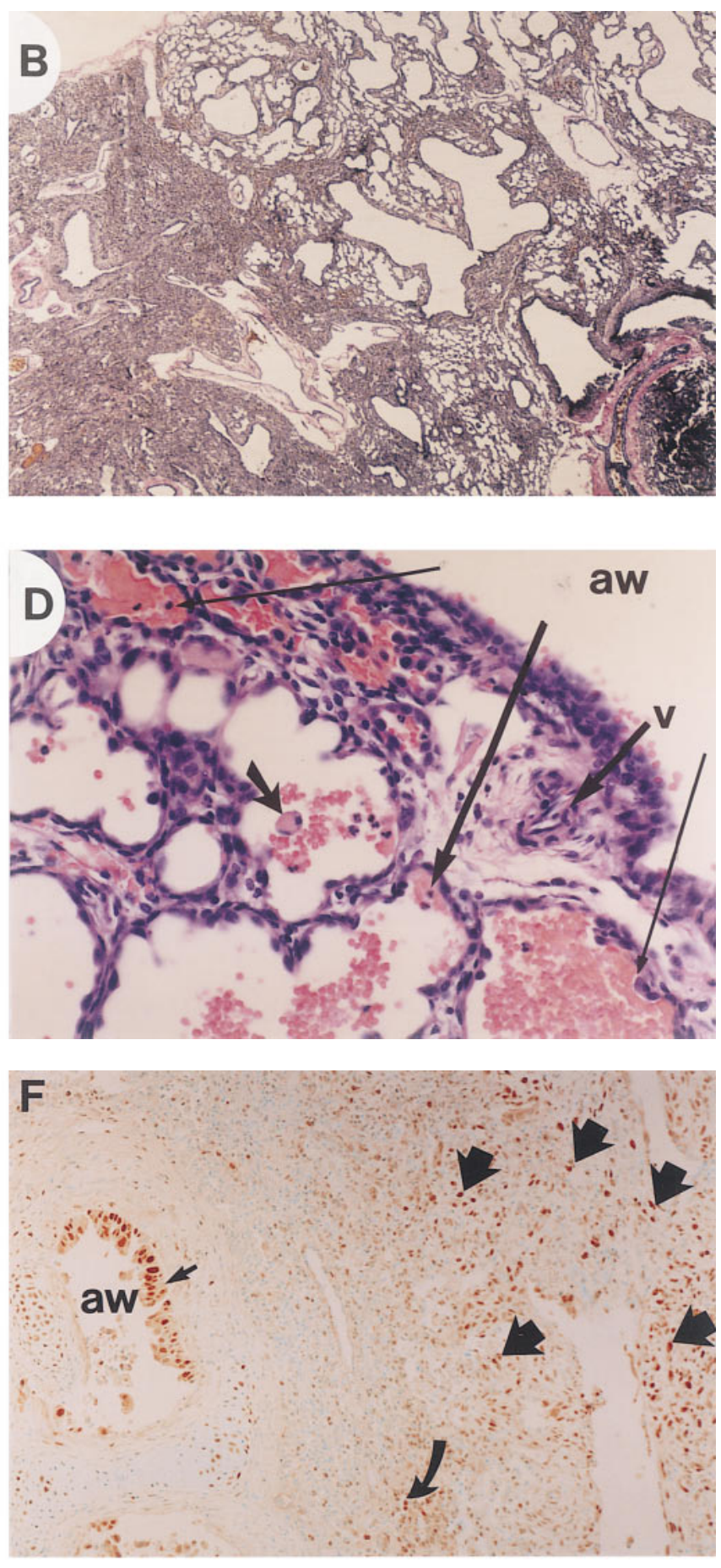

H

\section{aw}


ley Yoder, Southwest Foundation for Biomedical Research, San Antonio, TX).

To better understand potential factors contributing to these effects of 2A11, the OIs of the individual five 2A11treated baboons were analyzed (Fig. $3 C$ ). The animal having the most severe acute RDS (4N96) was male, consistent with the known effects of androgens in delaying fetal lung maturation (38) and hence the higher incidence of surfactant deficiency and acute respiratory distress syndrome in boys (39). Restricting our analysis to females only, 2A11-treated baboons $(n=4)$ had a consistently improved clinical course over the $6 \mathrm{~d}$ of treatment compared to animals in both the 140-d/PRN $(n=$ $8)$ and $140-\mathrm{d} / 100 \% \mathrm{O}_{2}(n=7)$ treatment groups (Fig. $\left.3 \mathrm{D}\right)$. It should be noted, however, that the RDS in the male baboon (4N96) did resolve and there was minimal evidence of chronic lung disease at $240 \mathrm{~h}$ in this animal.

Two of the female 2A11-treated animals (2Q96 and 6C96) developed late septicemia with acute pneumonia, leading to early death of one animal (2Q96). Although blood and sputum cultures were not positive in these animals being treated with multiple broad-spectrum antibiotics, profound leukopenia developed in parallel with altered hemodynamic parameters (markedly and suddenly decreased blood pressure that was refractory to therapy with volume and pressors), and was considered clinically pathognomonic of sepsis syndrome. Acute pneumonia represents a confounding factor that obscures clinical evidence for BPD. When analysis of the 5-10-d treatment interval was limited to animals without clinical evidence of septicemia (Fig. 3 E), the three 2A11-treated animals (two females plus one male) had improved OI compared to $140-\mathrm{d} /$ $100 \% \mathrm{O}_{2}$ animals not receiving the antibody, which was significant at the 240-h time point $(P<0.001)$.

Histopathologically, after $10 \mathrm{~d}$ of $100 \% \mathrm{O}_{2}$ treatment, there was little evidence of BPD in the five animals receiving 2A11 (Fig. 4). Low-power microscopic views of lung sections stained for elastic tissue demonstrated normal, well-developed alveolar architecture in 140-d/PRN animals (Fig. $4 A$ ) versus extensive fibrosis with atelectasis and severe saccular overdistension in $140-\mathrm{d} / 100 \% \mathrm{O}_{2}$ baboons with moderate to severe BPD (Fig. $4 \mathrm{~B}$ ). However, the $140-\mathrm{d} / 100 \% \mathrm{O}_{2}$ baboons treated with $2 \mathrm{~A} 11$ demonstrated only mild disruption of alveolar architecture (Fig. 4 C), with some mild saccular overdistension and minimal interstitial thickening. On higher power microscopic examination of hematoxylin and eosin-stained sections (Fig. $4 \mathrm{D}$ ) and sections stained with the trichrome method for collagen deposition (data not shown), the lungs from 2A11-treated animals manifested no evidence of peribronchiolar fibrosis (Fig. $4 \mathrm{D}$ ), which usually occurs as a characteristic feature of BPD (26, 27). There were scattered areas with focal interstitial fibrosis associated with intraalveolar hemorrhage and sparse neutrophilic infiltrates, consistent with resolving hyaline membrane disease (Fig. 4, C and D, arrows). Pathological evidence of intrapulmonary hemorrhage was present in a majority of both the $140-\mathrm{d} / 100 \% \mathrm{O}_{2}$ and the $140-\mathrm{d} / \mathrm{PRN}$ animals (all of which were ventilated and none of which received exogenous surfactant), and generally correlated with severity of acute RDS. Only the two animals which developed septicemia had more widespread, moderate to severe neutrophilic infiltrates, diagnostic of clinically significant acute pneumonia. Clinical and pathological evidence of septicemia typically occurs in $>5 \%$ of either $140-\mathrm{d} / 100 \% \mathrm{O}_{2}$ or $140-\mathrm{d} / \mathrm{PRN}$ animals (all of which had indwelling arterial lines).
Immunohistochemical analyses for proliferating cell nuclear antigen (PCNA) as a marker for proliferating cells revealed moderate labeling of predominantly the epithelial compartment in 140-d/PRN animals (Fig. 4 E) and intense labeling of both epithelium and distal lung mesenchyme in $140-\mathrm{d} / 100 \%$ $\mathrm{O}_{2}$ baboons, consistent with ongoing interstitial fibrosis (Fig. 4 $F)$. In contrast, there was marked reduction in PCNA labeling of lung parenchyma in 2A11-treated animals (Fig. $4 G$ ), in which most of the residual proliferating cells were epithelial in location.

\section{Discussion}

The present study demonstrates that elevated urine BLP between 24 and $72 \mathrm{~h}$ after birth is a reliable predictor of which preterm baboons will develop chronic lung disease similar to BPD in two different baboon models of BPD. This effect is apparent even when gender is eliminated as a variable, and all experimental and control animals were treated during the same time frame under the direction of a single neonatologist to control for variations in intensive care unit practices. The precise mechanism for increased urinary BLP at the two different gestational ages with differing $\mathrm{O}_{2}$ exposures is not known. Similarly, the precise pathophysiology of BPD is unknown: the role of immature antioxidant defenses in the 125-d PRN animals could undoubtedly play a role in the pathobiology of BPD in these extremely premature animals (32). Currently, there is no reliable epidemiological or biological marker for identifying which preterm human infants will go on to develop chronic lung disease (11). Furthermore, we demonstrate that postnatal administration of blocking anti-BLP antibody is protective against the development of clinical and pathological evidence of BPD: none of the five animals receiving anti-BLP blocking antibody manifested significant peribronchiolar fibrosis or widespread alveolar interstitial fibrosis. At least part of this effect is probably due to blockade of BLP function as a fibroblast growth factor, as evidenced by marked diminution in PCNA immunostaining in mesenchymal cells. Multiple molecular mechanisms underlying the anti-BLP antibody effect are likely, however, including decreased macrophage activation and blockade of direct effects of BLP as a bronchoconstrictor. It is unlikely that the late beneficial effect on the course of BPD is simply due to the early improvement in OI of anti-BLP antibody (2A11)-treated animals as compared to both the untreated $100 \% \mathrm{O}_{2}$ and $\mathrm{O}_{2}$ PRN animals: the male 2A11-treated animal (4N96) did develop severe RDS, but had minimal evidence of chronic lung disease after $10 \mathrm{~d}$ of $100 \% \mathrm{O}_{2}$.

Only a few potential adverse side effects of 2A11 are apparent. Histological analyses demonstrate scattered intraalveolar hemorrhages and sparse neutrophilic infiltrates in lung sections from all five 2A11-treated baboons, similar to 140-d/ $100 \% \mathrm{O}_{2}$ and 140-d/PRN animals, consistent with resolving hyaline membrane disease. This was most apparent in the male (4N96) after severe hyaline membrane disease which did resolve and did not appear to be correlated with adverse clinical outcome during the $10-\mathrm{d}$ treatment period. A more serious potential side effect appears to be an increased incidence of septicemia. It is possible that BLP might be important for phagocytic and/or bactericidal function of macrophages and/or granulocytes, but further studies are required to address this hypothesis. We cannot completely exclude the possibility that 
the two baboons became septic by chance alone, especially considering the presence of indwelling arterial lines and endotracheal tubes in these preterm animals. Of additional note, cultures of the antibody stocks remaining were negative for bacterial and fungal organisms. Nonetheless, this is an unexpected, interesting scientific observation that may shed light on the role of bombesin-like peptides during acute and chronic lung injury processes.

One further point of interest concerns the significant improvement in OI in all five 2A11-treated animals during the first $36 \mathrm{~h}$ of postnatal life. In our previous work, we demonstrated that BLP is important for type II cell differentiation and surfactant synthesis as well as generalized cell proliferation in both murine and human fetal lung in organ culture and in murine lung in utero (40-43). Subsequent work in other laboratories confirmed and extended this result to isolated rat primary type II cell cultures $(44,45)$, in which BLP stimulated surfactant secretion as well as synthesis (44). The highest endogenous BLP levels occur at mid-gestation in primate lung, but often peak effects of BLP occur at subnanomolar concentrations $(44,45)$. We postulate that $2 \mathrm{~A} 11$ might promote more efficient secretion of endogenous surfactant from type II cells by reducing local BLP concentrations to a more optimal concentration. High doses of BLP often downregulate biological effects, regardless of whether the cellular response is proliferative, synthetic, or secretory. Finally, we cannot exclude the possibility that the $2 \mathrm{~A} 11$ effect might be mediated via IgG1 Fc receptor function, with nonspecific modulation of macrophage function leading to altered cytokine production. Ideally, a double-blinded, randomized baboon trial should be carried out using 2A11 versus MOPC, an IgG1 of undefined specificity, to control for nonspecific IgG effects. The prohibitive expense and limited numbers of animals available for these studies have precluded carrying out these rigorous controls using the $140-\mathrm{d} / 100 \% \mathrm{O}_{2}$ model. Follow-up studies are aimed at indepth analyses with a paired irrelevant IgG1 murine monoclonal antibody control using the more clinically relevant $125 \mathrm{~d} /$ PRN model for mild-to-moderate BPD, which is most similar clinically and pathologically to current cases of human BPD.

These studies introduce the interesting concept of pulmonary NE cells as a component of the inflammatory response. We have demonstrated that cytokines such as TNF- $\alpha$ can induce neuroendocrine cell differentiation in human small cell lung cancer cell lines (46), which could explain the increased number of these cells in the lung of guinea pigs immunized systemically with ovalbumin (47). This would suggest that BPD might be viewed as an inflammatory response gone awry, and points to possible clinical usefulness of agents for blocking BLP receptor signaling during lung injury.

\section{Acknowledgments}

We thank the National Institutes of Health (NIH) for the support of the R-10 Collaborative Program in Bronchopulmonary Dysplasia, headed by Dr. Jacqueline Coalson, without which this work would not have been possible. Key R-10 support staff include D. Vicki Winters and the Pathology staff at University of Texas Health Sciences Center at San Antonio, and the NICU and animal production staffs at Southwest Foundation for Biomedical Research. We thank Dr. Carl White for the two RNA specimens on 140-d baboons treated with $\mathrm{O}_{2}$ for $24 \mathrm{~h}$. We are grateful to Dr. Mary Ellen Avery for encouragement, helpful discussions, and for critical review of this manuscript. We also thank Drs. Ann Stark, Linda van Marter, Jeffrey Drazen, and Lynne Reid for helpful discussions. We acknowledge the excellent technical assistance of Dr. QiQi Mu, Hai Dong, Aliakbar Shahsafaei, and the Histology Division of the Department of Pathology at Brigham \& Women's Hospital and histopathological analyses.

This work was supported by NIH grants \#U10-HL52638 (M.E. Sunday) and HL-52636 (resource grant).

\section{References}

1. Northway, W.H., R.C. Rosan, and D.Y. Porter. 1967. Pulmonary disease following respirator therapy of hyaline membrane disease. Bronchopulmonary dysplasia. N. Engl. J. Med. 276:357-368.

2. Parker, R.A., D.P. Lindstrom, and R.B. Cotton. 1992. Improved survival accounts for most, but not all of the increase in bronchopulmonary dysplasia. Pediatrics. 90:663-668.

3. Abman, S.H., and J.R. Groothius. 1994. Pathophysiology and treatment of bronchopulmonary dysplasia. Current issues. Pediatr. Clin. North Am. 41: $277-315$.

4. Hansen, T., and A. Corbet. 1991. Chronic lung disease-Bronchopulmonary dysplasia. In Diseases of the Newborn. H.W. Taeusch, R.A. Ballard, and M.E. Avery, editors. W.B. Saunders Co., Toronto. 519-526.

5. Ireys, H.T., G.F. Anderson, T.J. Shaffer, and J.M. Neff. 1997. Expenditures for care of children with chronic illnesses enrolled in the Washington state medicaid program, fiscal year 1993. Pediatrics. 100:197-204.

6. Avery, M.E., W.H. Tooley, J.B. Keller, S.S. Hurd, M.H. Bryan, R.B. Cotton, M.F. Epstein, P.M. Fitzhardinge, C.B. Hansen, T.N. Hansen, et al. 1987. Is chronic lung disease in low birth weight infants preventable? A survey of eight centers. Pediatrics. 79:26-30.

7. Watterberg, K.L., L.M. Derners, S.M. Scott, and S. Murphy. 1996. Chorioamnionitis and early lung inflammation in infants in whom bronchopulmonary dysplasia develops. Pediatrics. 97:210-215.

8. Jobe, A.H. 1993. Pulmonary surfactant therapy. N. Engl. J. Med. 328: 861-868.

9. Jobe, A.H., B.R. Mitchell, and H. Gunkel. 1993. Beneficial effects of the combined use of prenatal corticosteroids and postnatal surfactant on preterm infants. Am. J. Obstet. Gynecol. 168:508-513.

10. Konishi, M., T. Fujiwara, T. Naito, Y. Takeuchim, Y. Ogawa, K. Inukai, M. Fujimura, H. Nakamura, and T. Hashimoto. 1988. Surfactant replacement therapy in neonatal respiratory distress syndrome. Eur. J. Pharmacol. 147:20-25.

11. Feinberg, E., D.K. Richardson, H. Als, E. Sell, and R.B. Parad. 1997. Late pulmonary outcomes poorly predicted by early risk factors in very low birth weight infants. Pediatr. Res. 39:263a. (Abstr.)

12. Sunday, M.E., L.M. Kaplan, E. Motoyama, W.W. Chin, and E.R. Spindel. 1988. Biology of disease: gastrin-releasing peptide (mammalian bombesin) gene expression in health and disease. Lab. Invest. 59:5-24.

13. Sunday, M.E., C.G. Willett, K. Patidar, S.A. Graham, and D. Kelly. 1994. Modulation of oncogene and tumor suppressor gene expression in a hamster model of chronic lung injury with varying degrees of pulmonary neuroendocrine cell hyperplasia. Lab. Invest. 70:875-888.

14. Johnson, D.E., W.R. Anderson, and B.A. Burke. 1993. Pulmonary neuroendocrine cells in pediatric lung disease: alterations in airway structure in infants with bronchopulmonary dysplasia. Anat. Rec. 236:115-119.

15. Sunday, M.E. 1996. Neuropeptides and lung development. In Growth and Development of the Lung. J.A. McDonald, editor. Marcel Dekker, New York. 401-494.

16. Tanswell, A.K., L. Wong, F. Possmayer, and B.A. Freeman. 1989. The preterm rat: a model for studies of acute and chronic neonatal lung disease. $P e$ diatr. Res. 25:525-529.

17. Kessler, D.L., W.E. Truog, J.H. Murphy, S. Palmer, T.A. Standaert, D.E. Woodrum, and W.A. Hodson. 1982. Experimental hyaline membrane disease in the premature monkey: effects of antenatal dexamethasone. Am. Rev. Respir. Dis. 126:62-69.

18. Goetzman, B., L. Read, C. Plopper, A. Tarantal, C. George-Nascimento, T. Merrit, J. Whitsett, and D. Styne. 1994. Prenatal exposure to epidermal growth factor attenuates respiratory distress syndrome in rhesus infants. Pediatr. Res. 35:30-36.

19. Meredith, K.S., R.A. Delemos, J.J. Coalson, R.J. King, D.R. Gerstmann, R. Kumar, T.J. Kuehl, D.C. Winter, A. Taylor, R.H. Clark, and D.M. Null. 1989. Role of lung injury in the pathogenesis of hyaline membrane disease in premature baboons. J. Appl. Physiol. 66:2150-2158.

20. deLemos, R., J. Wolfsdorf, R. Nachman, A.J. Block, G. Leiby, H.A. Wilkinson, T. Allen, J.A. Haller, W. Morgan, and M.E. Avery. 1969. Lung injury from oxygen in lambs: the role of artificial ventilation. Anesthesiology. 30: 610-618.

21. Nilsson, R. 1982. The artificially ventilated preterm rabbit neonate as experimental model of hyaline membrane disease. Acta Anaesth. Scand. 26:89-103.

22. Lorenzo, A.V. 1985. The preterm rabbit: a model for the study of acute and chronic effects of premature birth. Pediatr. Res. 19:201-205.

23. Han, R.N., S. Buch, I. Tseu, J. Young, N.A. Christie, H. Frndova, S.J. 
Lye, M. Post, and A.K. Tanswell. 1996. Changes in structure, mechanics, and insulin-like growth factor-related gene expression in the lungs of newborn rats exposed to air or $60 \%$ oxygen. Pediatr. Res. 39:921-929.

24. Veness-Meehan, K.A., B.M. Moats-Staats, W.A. Price, and A.D. Stiles. 1997. Re-emergence of a fetal pattern of insulin-like growth factor expression during hyperoxic rat lung injury. Am. J. Respir. Cell Mol. Biol. 16:538-548.

25. Pierce, R.A., K.H. Albertine, B.C. Starcher, J.F. Bohnsack, D.P. Carlton, and R.D. Bland. 1997. Chronic lung injury in preterm lambs: disordered pulmonary elastin deposition. Am. J. Physiol. 272:L452-L460.

26. Escobedo, M.B., J.L. Hilliard, F. Smith, K. Meredith, W. Walsh, D. Johnson, J.J. Coalson, T.J. Kuehl, D.M. Null, and J.L. Robotham. 1982. A baboon model of bronchopulmonary dysplasia. I. Clinical features. Exp. Mol. Pathol. 37:323-334.

27. Coalson, J.J., T.J. Kuehl, M.B. Escobedo, J.L. Hilliard, F. Smith, K. Meredith, D.M. Null, W. Walsh, D. Johnson, and J.L. Robotham. 1982. A baboon model of bronchopulmonary dysplasia. II. Pathologic features. Exp. Mol. Pathol. 37:335-350.

28. Delemos, R.A., and J.J. Coalson. 1992. The contribution of experimental models to our understanding of the pathogenesis and treatment of bronchopulmonary dysplasia. Clin. Perinatol. 19:521-539.

29. Coalson, J.J., V.T. Winter, D.R. Gerstmann, S. Idell, R.J. King, and R.A. Delemos. 1992. Pathophysiologic, morphometric, and biochemical studies of the premature baboon with bronchopulmonary dysplasia. Am. Rev. Respir. Dis. 145:872-881.

30. Seidner, S., P. Curnin, J.J. Coalson, D. Cornell, and R. Castro. 1993. A new model of chronic lung injury in surfactant treated baboons. Pediatr. Res. 33:344a. (Abstr.)

31. Coalson, J.J., V. Winter, and B. Yoder. 1997. Dysmorphic vascular development in premature baboons with bronchopulmonary dysplasia (BPD). Am. J. Respir. Crit. Care Med. 155:262a. (Abstr.)

32. Northway, W.H. 1992. Bronchopulmonary dysplasia: twenty-five years later. Pediatrics. 89:969-973.

33. Haley, K.J., J.M. Drazen, R. Osatahnondh, and M.E. Sunday. 1997. Comparison of the ontogeny of protein gene product 9.5, chromogranin A and proliferating cell nuclear antigen in developing human lung. Microscopy Res. Tech. 37:62-68.

34. Culling, C.F.A., R.T. Allison, and W.T. Barr. 1985. Cellular Pathology Technique. Butterworths, London. 153 pp.

35. Sunday, M.E., N. Choi, E.R. Spindel, W.W. Chin, and E.J. Mark. 1991. Gastrin-releasing peptide gene expression in small cell and large cell undifferentiated lung carcinomas. Hum. Pathol. 22:1030-1039.
36. Sunday, M.E., H.J. Wolfe, B.A. Roos, W.W. Chin, and E.R. Spindel. 1987. Gastrin-releasing peptide gene expression in developing, hyperplastic, and neoplastic human thyroid C-cells. Endocrinology. 122:1551-1558.

37. Avis, I.L., T.O.G. Kovacs, P.G. Kasprzyk, A.M. Treston, R. Bartholomew, J.H. Walsh, F. Cuttitta, and J.L. Mulshine. 1991. Preclinical evaluation of an anti-autocrine growth factor monoclonal antibody for treatment of patients with small cell lung cancer. J. Natl. Cancer Inst. 83:1470-1476.

38. Floros, J., H.C. Nielsen, and J.S. Torday. 1987. Dihydrotestosterone blocks fetal lung fibroblast-pneumonocyte factor at a pretranslational level. $J$. Biol. Chem. 262:13592-13598.

39. Hansen, T., and A. Corbet. 1991. Disorders of the transition. In Diseases of the Newborn. H.W. Taeusch, R.A. Ballard, and M.E. Avery, editors W.B. Saunders Co., Toronto. 498-514.

40. Sunday, M.E., J. Hua, H.B. Dai, A. Nusrat, and J.S. Torday. 1990 Bombesin increases fetal lung growth and maturation in utero and in organ culture. Am. J. Respir. Cell Mol. Biol. 3:199-205.

41. Sunday, M.E., J. Hua, B. Reyes, H. Masui, and J.S. Torday. 1993. Antibombesin antibodies modulate fetal mouse lung growth and maturation in utero and in organ cultures. Anat. Rec. 236:25-32.

42. Sunday, M.E., J. Hua, J. Torday, B. Reyes, and M.A. Shipp. 1992. CD10/Neutral endopeptidase 24.11 in developing human fetal lung: patterns of expression and modulation of peptide-mediated proliferation. J. Clin. Invest. 90:2517-2525

43. King, K.A., J. Hua, J.S. Torday, J.M. Drazen, S.A. Graham, M.A. Shipp, and M.E. Sunday. 1993. CD10/Neutral endopeptidase regulates fetal lung growth and maturation in utero by potentiating endogenous bombesin-like peptides. J. Clin. Invest. 91:1969-1973.

44. Asokananthan, N., and M.H. Cake. 1996. Stimulation of surfactant lipid secretion from fetal type II pneumocytes by gastrin-releasing peptide. Am. J. Physiol. 270:L331-L337.

45. Fraslon, C., and J.R. Bourbon. 1992. Comparison of effects of epidermal and insulin-like growth factors, gastrin releasing peptide and retinoic acid on fetal lung cell growth and maturation in vitro. Biochim. Biophys. Acta. 1123:6575 .

46. Haley, K.J., K. Patidar, F. Zhang, R.L. Emanuel, and M.E. Sunday 1998. Tumor necrosis factor induces neuroendocrine differentiation in small cell lung carcinoma cell lines. Am. J. Physiol. In press.

47. Bousbaa, H., F. Poron, and J. Fleury-Feith. 1994. Changes in chromogranin A-immunoreactive guinea-pig pulmonary neuroendocrine cells after sensitization and challenge with ovalbumin. Cell Tissue Res. 275:195-199. 